\title{
縮尺模型実験による夜間街路の光環境に対する明るさ感と 活動性印象の評価指標の検討 \\ EVALUATION OF BRIGHTNESS AND ACTIVITY IMPRESSIONS OF OUTDOOR SPACE BY A SCALE MODEL EXPERIMENT
}

\author{
持 永 愛 美*, 石田 泰一郎**
}

Aimi MOCHINAGA and Taiichiro ISHIDA

\begin{abstract}
In our previous study, we proposed two indexes for the brightness and activity impressions for outdoor lighting environments in the night-time using street images. In this study, we tested the effectiveness of these indexes using a scaled street model. Subjects evaluated the psychological impressions, brightness, activity, anxiety, harmony, comfort and preference. Based on the results, the median value of the road surface luminance highly correlates with brightness impression. It is also shown that the activity impression could be predicted based on the median value of the road surface luminance and the number of locally bright area. We validate two indexes of brightness and activity impressions.
\end{abstract}

Keywords : night, outdoor scene, brightness, activity, luminance of road surface, luminance distribution 夜間, 街路, 明るさ感, 活動性, 路面輝度, 輝度分布

\section{1. はじめに}

夜間の街路照明の設計基準は、歩行、交通などの安全性の確保や 犯罪防止のために、路面の障害物、対向者の顔や様子など視対象の 視認性の向上を目的として水平面照度や鉛直面照度が定められてい る $^{12)}$ 。しかし、夜間の街路空間における光源の特性、光の分布や存 在は視対象の見え方だけではなく、その空間の印象にも大きな影響 を与えると言える。例えば、街路の奥まった空間に照明を配置する

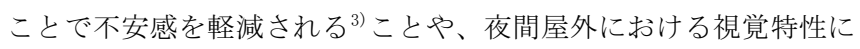
着目し、光源の分光分布が夜間街路空間の明るさ感印象に影響を与 えることなどが報告されている(4)-7)。近年では、夜間における人々 の活動が増え、夜間の街路空間においても質の高い快適な環境が望 まれるようになった。このことから、視認性を重視した照明設計だ けでなく、雰囲気性など人の主観的な印象も考慮した総合的な夜間 街路に対する計画が必要である。

室内空間の光環境については、従来より照明レベルや空間内の光 の分布による室内空間の心理印象への影響が示されてきた ${ }^{8)}$ 。室内

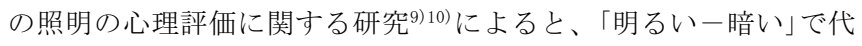
表される「明るさ感やや活気がある一活気がない」な゙で構成される 「活動感」は、室内空間の主な印象と考えられる。また、「快適一不 快」、「好き一嫌い」、「調和一不調和」など、その照明環境の総
合的な印象である「評価性」も重要な印象である。これら心理的印 象の評価指標や影響を与える物理的特性に関寸る研究が多くなされ

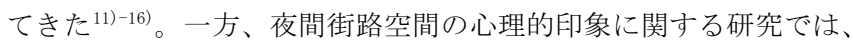
街路に対する心理評価を構成する因子に関するものや、昼夜によっ て抽出される因子の違いに関寸るものが多くなされている17)18)。た だし、それらの研究では街路における様々な構成要素から得られる 街路の印象についてを扱っており、街路における照明要素の物理的 特性と心理的印象との関係については定性的な検討に留まっている ものが多く、夜間街路の心理的印象に影響を与える光の物理的特性 に関して明確な関係が明らかとなっていない。

筆者らは屋外環境である夜間街路空間の光環境に着目し研究を進 めている。これまでに夜間街路の画像を用いた印象評価実験を実施 し、明るさ感および活動性印象の評価指標の提案を行った $\left.{ }^{19)} 20\right)$ 。明 るさ感については、路面の輝度分布のベースとなる輝度レベルが影 響を与えることを見出し，その代表值として路面輝度の中央值が良 好な指標となることを示した ${ }^{19)}$ 。活動性については、空間の明るさ および空間内の光の分布が影響を与えることを見出し、路面輝度の 中央值および局所的に明るい領域（以後、局所的明所領域）の数を 変数とした指標を提案した ${ }^{20)}$

これらの先行研究 $\left.{ }^{192} 20\right)$ では、被験者の観察刺激として夜間街路の
$*$ 京都大学大学院工学研究科建築学専攻 博士後期課程・修士 (生活デザイン) 独立行政法人日本学術振興会 特別研究員 DC

** 京都大学大学院工学研究科建築学専攻 准教授. 工博
Graduate Student, Graduate School of Engineering, Kyoto University, M. Life Des.

Research Fellow, Japan Society for the Promotion of Science Assoc. Prof., Graduate School of Engineering, Kyoto University, Dr. Eng. 
プロジェクターによる投影画像を使用した。それによって多様な街 路を評価対象とすることができ、特定の街路に限定されない一般性 を期待できる評価指標を提案することができた。一方、投影画像を 用いたことによって、現実空間における照明や路面などの輝度は忠 実には再現できていない。特に高輝度領域はプロジェクターの上限 輝度によって制約があった。また、現実の街路画像を採用したため、 自動車、人物、立地条件など光環境要素以外の事物の影響が夜間街 路の印象評価に含まれていたことが考えられる。

そこで本報では、画像評価実験において示した明るさ感および活 動性評価指標の有効性を検証することを目的として、輝度をより現 実に近い值に再現することや、照明以外の街路の形状、人物や自動 車などを統制した条件を設定するために、照明の調光や点灯パター ンの組み合わせが可能な夜間街路の縮尺模型を用いた主観評価実験 を行った。本報では、明るさ感および活動性の評価指標の検証結果 に加え、不安感、および調和感、快適性、嗜好性の評価について検 討した結果を報告する。

\section{2. 実験方法}

\section{1 実験装置}

図 1 に実験装置を示す。実験室内に製作した街路の両脇に建物が 並列する縮尺 $1 / 50$ の街路模型を用いて心理評価実験を実施した。 本実験では、夜間街路の光の特徴量と心理的印象との関係を明確に
するために、街路の立地条件や建物の形状、色彩など光環境要素以 外の影響をできるだけ排除し、街路の場所の用途や地域は特定しな い抽象化した街路模型を製作した。街路の幅は実寸法 $7.5 \mathrm{~m} 、$ 建物は 実寸法で幅 $8 \mathrm{~m}$ 、高さ $6 \mathrm{~m}$ とし、2 階建ての建物を想定した。路面は N2、建物はN9 およびN5 相当の紙を用いた。また、街路の路面輝度 および局所的明所領域数を調整するために、街路模型の上部、建物、 および路面に光源を設置した。

\section{2 照明条件}

本実験で設定した照明パターンとその路面の輝度の中央值を表 1 および表 2 に示す。模型内に設置した各照明の組合せとして、まず 路面輝度の調節用として設置した照明（以後、路面照明と記す）に よって路面の輝度分布を 2 パターン（均一・不均一）設定し、それ に街路空間内の照明器具などを想定した鉛直および路面に設置した 照明（以後、局所照明と記す）を組み合わせた。

路面照明および局所照明の出力は、JIS ${ }^{1}$ で設定された基準值を参 考に、路面中央における鉛直面照度值に基づいて設定した。

図 2 に路面照明条件による模型街路の光分布の写真を示す。路面 照明の具体的な照明方法は、街路模型の上部に設置した蛍光灯およ びLED によるスポット照明を用いて、路面の光の分布を均一および 不均一に変化させた。均一条件では点灯出力レベルを low, middle, high の条件で表す 3 段階設定した。不均一条件ではスポット照明の 点灯数を 4 灯および 8 灯の 2 条件設定し、さらに各条件に対し点灯

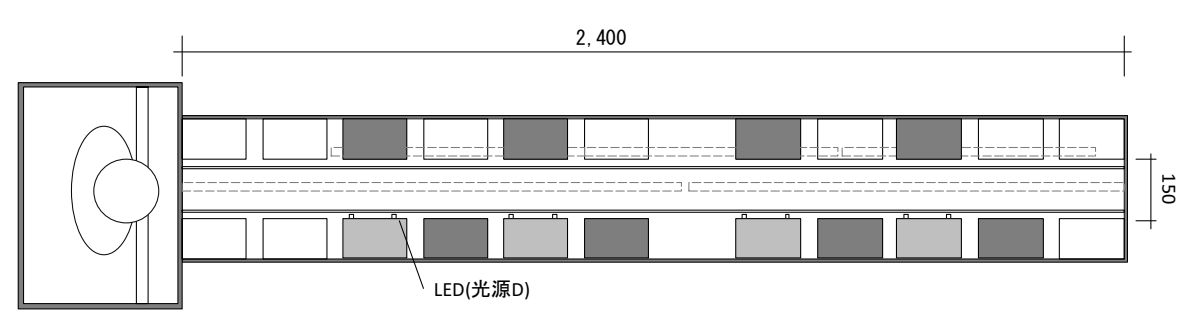

a) 平面図

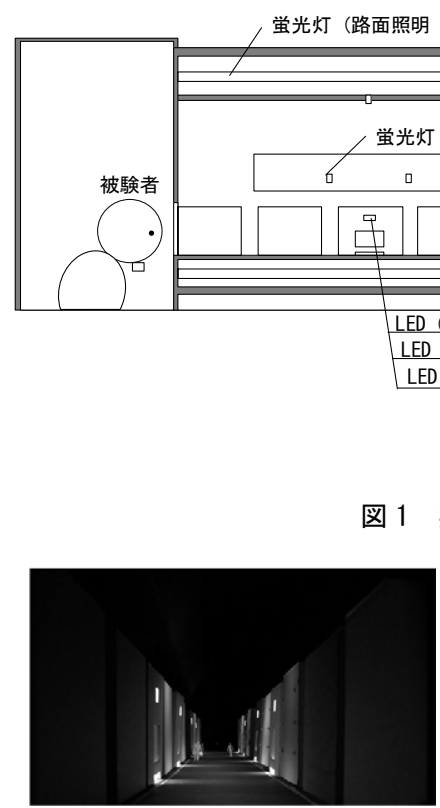

a) Uh_AC b）側面図

図 1 実験装置平面図および側面図

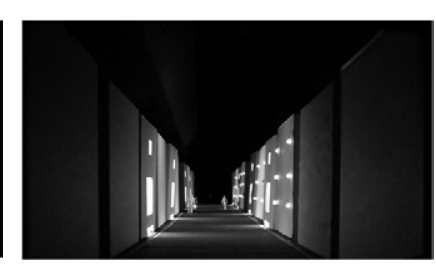

b) Um_ABCD

図 5 照明条件の例

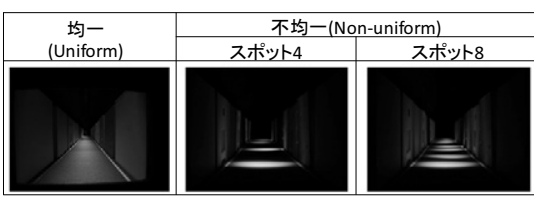

図 2 路面照明の点灯パターン

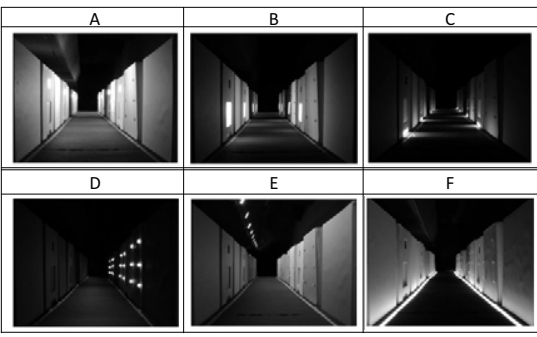

図 3 局所照明の点灯パターン
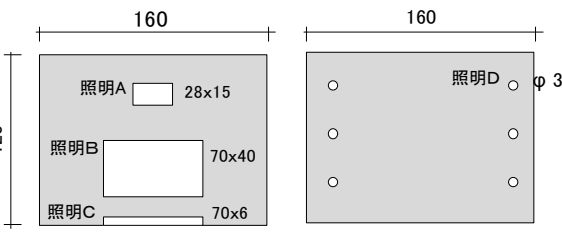

図 4 光源設置建物立面図

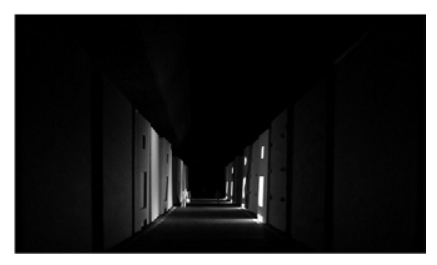

c) OFFr_ABC

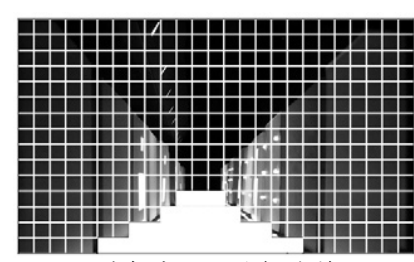

*白色グリッドが路面領域

図 6 グリッド分割と 路面領域の選択 
出力を low, high の 2 段階設定した。図 2 に示すように路面照明の 光源は、被験者からは見えないようになっている。これは、街路中 で被験者から見えている光源の数や発光強度を変えずに、路面の輝 度を何段階か変化させるというような条件設定を可能にするための 工夫である。ただし、路面照明の光源は視野内に存在しておらず、 現実の街路空間とは異なる状況となっている。被験者の内観では、 このことによって模型街路の照明が特に不自然に感じられるという ような報告はなかった。高い位置に存在する街路照明が視野に入っ ていない、あるいはその存在を意識していないという状況に該当す るといえるだろう。ただし、現実空間においては、街路照明の存在 は明るさ感、活動性などに何らかの影響を与えるはずである。本研 究の結果は、今後、現実空間における街路照明も含めた印象評価結 果との比較検討が必要だろう。

図3に局所照明の点灯条件による模型街路の光分布パターンの写 真を示す。局所照明としては、日常環境において、我々がよく目に する照明のみならず、LEDや有機ELなど新たな光源の特徴を有効利用 できると思われる照明を模型内のバランスを考えて配置した。照明A は建物壁面の上部、照明Bは建物壁面の中部、照明Cは建物壁面の下 部に設置した。また、照明Dは比較的小さい面積で高輝度な光源、照 明Eは街路空間の上方から全体を照明する光源、照明Fは路面から上
方へ照明する光源となっている。図4に照明A、B、CおよびDを設置し た建物の立面図を示す。表1および表2に示す局所照明の詳細欄の記 述について説明する。基準条件では鉛直面照度に基づき各々設定し た局所照明の出力で点灯している。出力減は、基準条件から局所照 明の点灯出力を下げた条件である。また、点灯減とは、街路の両側 に設置された照明A、BおよびCのうち、街路の右側のみを点灯した条 件である。図5に路面照明と局所照明を組み合わせた条件による模型 内部の光分布例を示寸。

路面照明の不均一用スポット照明および照明 A、B、C、D には白色 LED (Linkman BL304W1CA1B02)を用いた。また、路面照明の均一用照 明および照明 E、F には昼白色蛍光灯 (Panasonic FLR40S EX-D/M, FLR20S EX-D/M) を用いた。また、各照明の S/P 比を分光放射照度計 （KONICA MINOLTA CL-500A）を用いて測定した結果、白色LED は2.56、 昼白色蛍光灯は 2.12 であり、その差は大きくない。したがって、こ れらの光源を低照度で使用したとしても、分光分布の違いによる明 るさの相対関係に大きな変化は生じないものと考えられる。

以上の通り、路面照明と局所照明の出力および点灯数を組み合わ せた照明条件によって、計104条件を設定した。

\section{3 模型内と実空間の輝度の比較}

模型内の輝度測定は、色彩輝度計（KONICA MINOLTA CS-200）およ

表 1 各照明条件における路面輝度の中央値 $\left[\mathrm{cd} / \mathrm{m}^{2}\right]$

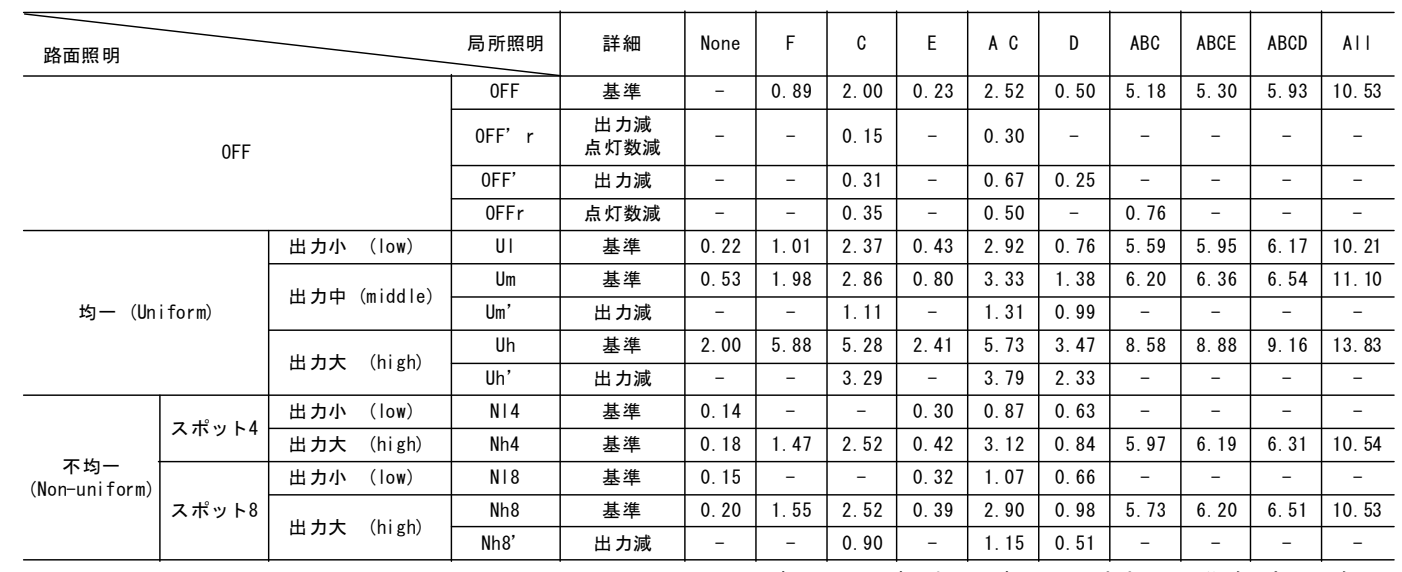

$\mathrm{A}$ : 壁面上, $\mathrm{B}$ :壁面中， $\mathrm{C}$ :壁面下, $\mathrm{D}$ :点光源, $\mathrm{E}$ : 街路上部, $\mathrm{F}$ : 路面

表 2 路面照明を組み合わせた照明条件における路面輝度の中央值 $\left[\mathrm{cd} / \mathrm{m}^{2}\right]$

\begin{tabular}{|c|c|c|c|c|c|c|c|c|c|c|c|c|c|c|}
\hline \multicolumn{3}{|l|}{ 路面照明 } & 局所照明 & 詳細 & None & $\mathrm{F}$ & $c$ & $E$ & $A C$ & D & $\mathrm{ABC}$ & ABCE & $A B C D$ & All \\
\hline \multicolumn{2}{|c|}{ 均一 (Uniform) } & 出カ小 $\quad($ low $)$ & \multirow[b]{2}{*}{$\mathrm{UI}+\mathrm{Nh} 8$} & \multirow[b]{2}{*}{ 基準 } & \multirow[b]{2}{*}{0.16} & \multirow[b]{2}{*}{ 1. 41} & \multirow[b]{2}{*}{0.42} & \multirow[b]{2}{*}{0.29} & \multirow[b]{2}{*}{0.73} & \multirow[b]{2}{*}{0.34} & \multirow[b]{2}{*}{1.76} & \multirow[b]{2}{*}{ 2. 26} & \multirow[b]{2}{*}{ 2. 09} & \multirow[b]{2}{*}{ 4. 46} \\
\hline $\begin{array}{c}\text { 不均一 } \\
\text { (Non-uni form) }\end{array}$ & スポット8 & 出カ大 (high) & & & & & & & & & & & & \\
\hline \multicolumn{2}{|c|}{ 均一 (Uniform) } & 出カ中 (middle) & \multirow[b]{2}{*}{ Um+Nh4 } & \multirow[b]{2}{*}{ 基準 } & \multirow[b]{2}{*}{0.21} & \multirow[b]{2}{*}{ 1. 62} & \multirow[b]{2}{*}{0.54} & \multirow[b]{2}{*}{0.36} & \multirow[b]{2}{*}{0.83} & \multirow[b]{2}{*}{0.45} & \multirow[b]{2}{*}{ 1. 84} & \multirow[b]{2}{*}{ 2. 40} & \multirow[b]{2}{*}{ 2. 25} & \multirow[b]{2}{*}{ 4. 54} \\
\hline $\begin{array}{c}\text { 不均一 } \\
\text { (Non-uniform) }\end{array}$ & スポット4 & 出カ大 (high) & & & & & & & & & & & & \\
\hline
\end{tabular}

表 3 評価項目および評価尺度

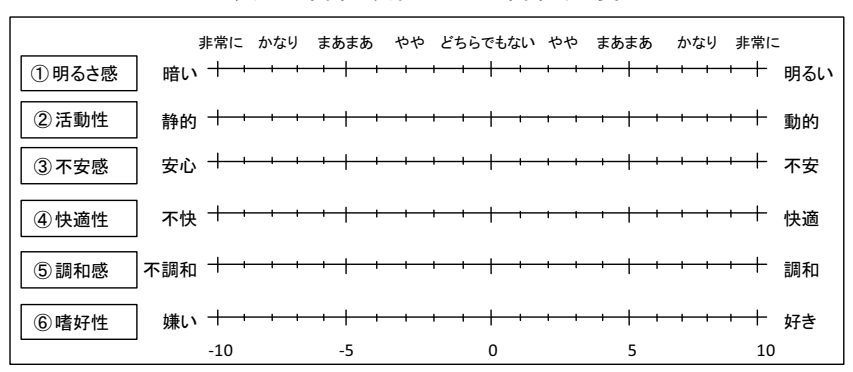

表 4 評価項目間の相関係数 R

\begin{tabular}{r|rrrrrr}
\hline & 明るさ感 & 活動性 & 不安感 & 調和感 & 快適性 & 嗜好性 \\
\hline 明るさ感 & 1 & & & & & \\
活動性 & 0.90 & 1 & & & & \\
不安感 & -0.96 & -0.83 & 1 & & & \\
調和感 & 0.60 & 0.41 & -0.75 & 1 & & \\
快適性 & 0.85 & 0.72 & -0.93 & 0.89 & 1 & \\
嗜好性 & 0.77 & 0.63 & -0.88 & 0.94 & 0.97 & 1 \\
\hline
\end{tabular}


びデジタルカメラ（Canon PowerShot G11）を用いた方法により行っ た ${ }^{* 1}$ 。実際の夜間街路空間の輝度值と本実験で用いた模型街路の輝 度值の比較を行うため、25 か所の実際の街路でデジタルカメラを用 いた輝度測定のための写真撮影を行い、得られた画像データから輝 度值を算出した。その結果、全街路のうち最大輝度值は約 $18800 \mathrm{~cd} / \mathrm{m}^{2} 、$ 最小輝度値は $0.01 \mathrm{~cd} / \mathrm{m}^{2}$ であった。また、測定地点毎の撮影範囲全 体の輝度平均值は $0.32 \sim 103.17 \mathrm{~cd} / \mathrm{m}^{2}$ 、中央值は $0.17 \sim 19.92 \mathrm{~cd} / \mathrm{m}^{2}$ であった。一方、本実験で用いた模型内の輝度は、最大值が $6566 \mathrm{~cd} / \mathrm{m}^{2} 、$ 最小值は実空間と同様に $0.01 \mathrm{~cd} / \mathrm{m}^{2}$ であった。また照明条件毎の模 型街路の輝度平均値は $0.14 \sim 5.28 \mathrm{~cd} / \mathrm{m}^{2}$ 、中央値は $0.13 \sim 5.28 \mathrm{~cd} / \mathrm{m}^{2}$ であった。模型内の最大輝度值は実空間に比べ約 $1 / 3$ となったが、 実際の街路の場所によって、最大輝度が約 $1600 \mathrm{~cd} / \mathrm{m}^{2}$ や約 $3000 \mathrm{~cd} / \mathrm{m}^{2}$ の場所もあり、模型内の輝度は実際の街路空間における輝度の範囲 を再現できていると言えるだろう。

\section{4 模型街路の輝度情報の分析}

本実験の結果分析では、主として模型街路の心理印象評価と輝度 情報との関係を検討した。そのための模型街路内の輝度情報の取得 は、下記のような方法によって行った。まず、それぞれの照明条件 による模型内部を上述のデジタルカメラで撮影する。得られた画像 $1045 \times 625$ pixe1を視角 $2^{\circ}$ に相当する大きさの正方形のグリッド 25 $\times 15$ で分割し、各グリッド内の平均輝度を算出した。次に路面に相 当するグリッドの領域を選択し、その領域に含まれるグリッドから 路面の輝度分布の算出を行った。図6にグリッド分割および路面領域 の選択を示す。

\section{5 実験概要}

被験者は各照明条件による模型内部を 1 分間観察した後に、夜間 街路空間の印象評価を行った。夜間街路空間に対する主要な心理的 印象は、室内空間の光環境に対する心理的印象と共通するものがあ り、それに加えて夜間街路に特有の印象が重要になると考えた。本 研究では、共通の心理的印象として、空間の明るさの印象である「明 るさ感」、活気や落ち着いた印象である「活動性」、空間に対する光 の「調和感」「快適性」および「嗜好性」の 5 項目を設定した。さ らに、夜間街路で重要である防犯性や安全性に関係する「不安感」 を加え、計 6 項目を設定した。評価実験では、これら 6 項目を 21 段階の評価尺度で評価させた。表 3 に評価項目および評価尺度を示 す。

被験者は、建築学科の学生および教員 17 名 (男性 9 名、女性 8 名、
平均年齢 25 歳) であり、一人 1 回の評価を行った。各条件の提示順 序は被験者ごとにランダムとした。

\section{3. 実験結果}

\section{1 各心理的印象評価間の関係}

各照明条件に対する印象評価について、被験者間の評価の平均值 をもとに評価項目相互の相関係数を求めた。表 4 に各評価項目同士 の相関係数を示す。明るさ感、活動性および不安感の相関係数が 0.80 以上と高いことがわかる。また、調和感、快適性、および嗜好 性の各評価項目間においても、同様にそれぞれ相関係数が 0.85 以上 と相関が高い結果が得られた。また、不安感については、調和感と の相関係数は-0.75 であるが、その他の 4 つの印象評価との相関係 数は 0.80 以上であり、多くの心理的印象と関係することがわかる。 明るさ感と活動性、不安感、快適性との関係を図 7 に示す。明る さ感と活動性との関係は、活動性が低い条件でややばらつきが見ら れるが、高い正の相関関係であることがわかる。明るさ感と不安感 では、ほぼ直線上に評価が位置し、不安感は明るさ感と強く相関す ることがわかる。一方、明るさ感と快適性についても正の相関関係 が見られ、明るさ感が高くなるほど快適性の印象も高くなるが、あ る程度以上の明るさ感になると快適性の評価があまり上がらない傾 向となった。夜間街路空間における快適性は、単に街路の明るさに 依存するわけではないことが示唆される。

心理印象評価の相互関係の傾向としては、明るさ感および活動性 と、調和性、快適性および嗜好性の 2 つのグループに分けられ、不 安感はこれら 2 つのグループの双方に関わっていることが示された。 特に不安感の印象は明るさ感および快適性との相関が高く、雾囲気 性を考慮した照明設計を考える必要があると言える。

\section{2 各心理的印象評価と照明条件との関係}

図 8 から図 13 に各評価項目と全照明条件との関係を示す。横軸が 路面照明による照明条件であり、横軸の左側から路面照明の基本条 件、路面照明を組み合わせた条件、さらに局所照明を減光した条件、 局所照明の点灯数を減灯した条件、および局所照明を減光かつ減灯 した条件をとっている。それぞれの区分においては、点灯数および 出力の低い順に並んでいる。縦軸は、局所照明の点灯の組み合わせ を示しており、縦軸の上になるほど点灯数が多くなる。戝中のプロ ット内の数值は被験者平均值であり、白プロットは被験者平均值が 正の值、灰プロットは負の值である。

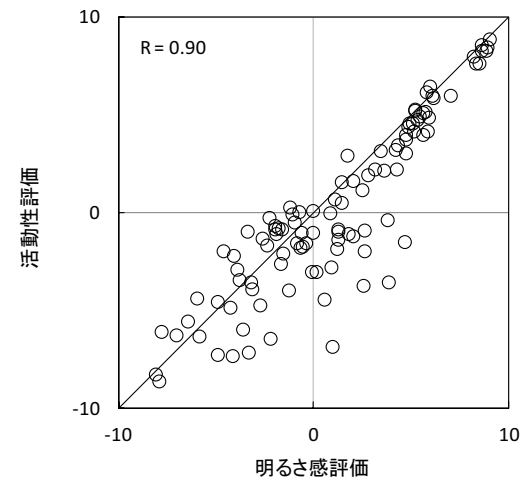

a）明るさ感と活動性

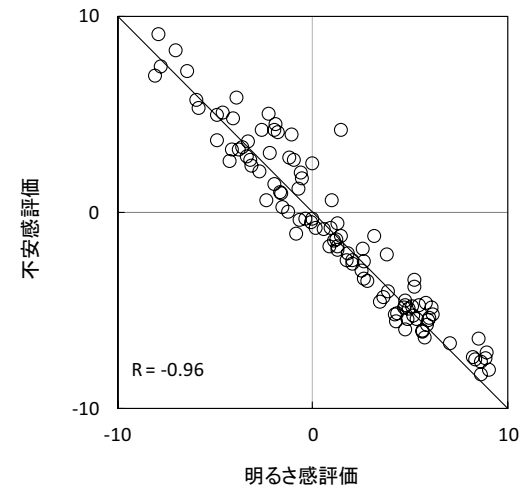

b）明るさ感と不安感

図 7 各評価項目同士の関係

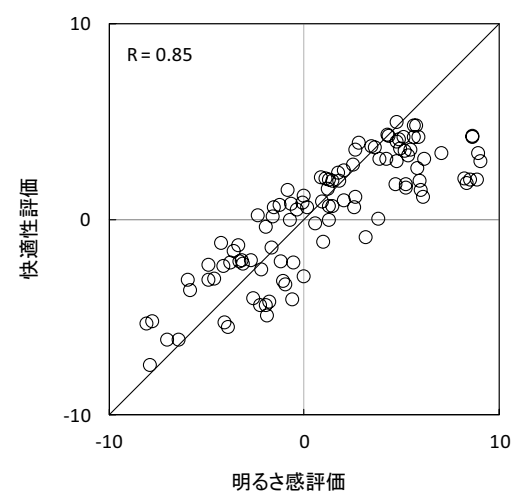

c）明るさ感と快適性 
図 8 に明るさ感評価結果を示す。全体的な傾向として局所照明の 点灯数が多くなるほど、明るさ感が増す傾向であることがわかる。 また、同一の局所照明条件における路面照明条件に着目寸ると、同 じ路面照明条件であれば、点灯出力が高い条件で明るさ感が高く評 価されていることも見て取れる。局所照明の点灯数が多い条件で明 るさ感が高い結果が得られたが、このことから局所的な高輝度領域 が街路の明るさ感に直接作用していたと即断することはできない。 局所照明の点灯数が増加するのに応じて路面や建物の鈶直面の全体

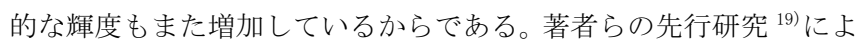
ると、路面の全体的な輝度分布が街路空間の明るさ感に強く影響す ることが明らかとなっている。模型街路の輝度情報に基づいた結果 の分析は次の節で行うことにする。

図 9 に活動性評価結果を示す。局所照明の点灯数が多くなるほど 活動性が増加する傾向であることがわかる。これは明るさ感と同様 の傾向であるが、明るさ感で見られた路面照明の点灯出力による効 果は、活動性では顕著ではない。

図 10 に不安感評価結果を示す。局所照明の点灯数が多いほど、不 安感が低くなる傾向が見られる。図 7 に示された通り明るさ感の結 果と類似した結果と言える。個別の照明条件について見てみると、 照明 D の場合にやや不安感が増寸傾向があった。これは、高輝度の 光源が単調に配列していることなどの特徵が影響している可能性が 考えられる。

図 11 に調和感評価結果を示す。調和感の評価のピークは、局所照 明の点灯数が多い縦軸の ALL や $\mathrm{ABCD}$ ではなく、 $\mathrm{AC} \sim \mathrm{ABCE}$ の条件付 近にあることがわかる。街路の明るさと照明パターンの何らかのバ ランスが調和感をもたらすと考えるべきだろう。また、高輝度光源
の単調な配列である照明 D の調和感が特別に低い結果が得られた。 ALL や ABCD 条件の調和感が低くなった結果も照明 D を含んでいたこ とが影響しているかもしれない。照明の配列と調和感の関係は興味 深い問題であるが、本研究では特徵的な結果を指摘することにとど める。

図 12 に快適性評価結果を示す。調和感と似た評価傾向であるが、 局所照明の点灯がない条件 (None) において快適性が特に低くなる結 果が得られた。これは調和感の結果と異なる点である。

図 13 に嗜好性評価結果を示す。快適性の結果と類似した結果と言 える。

\section{3 各心理評価と光環境の物理的特徵量との関係}

\section{3.1 明るさ感評価}

先行研究 ${ }^{19)}$ において、著者らは夜間街路空間の明るさ感印象と路 面領域内の輝度度数分布の中央值が良好な相関を示すことを見出し、 夜間街路の明るさ感の有効な評価指標となり得ることを提案した。 人が感じる街路空間の明るさ感は、その空間に拡がっている光の量 に影響され、その光の量は路面のベースとなる明るさを構成する量 （輝度度数分布の中央值）によって代表させることができる、とい う考え方である。

そこで本実験の結果に対して路面輝度の中央值が明るさ感の指標 として有効であるかどうか検討した。比較対象として、路面輝度の 平均值も検討する。なお、路面領域の輝度情報は 2.4 で述べた方法 により算出した。路面輝度の平均值と明るさ感評価との関係を図 14 に、路面輝度の中央值と明るさ感評価との関係を図 15 に示寸。路面 輝度の平均值は明るさ感と正の相関を示すものの、同程度の輝度平 均值であっても明るさ感に大きなばらつきがあることがわかる。一

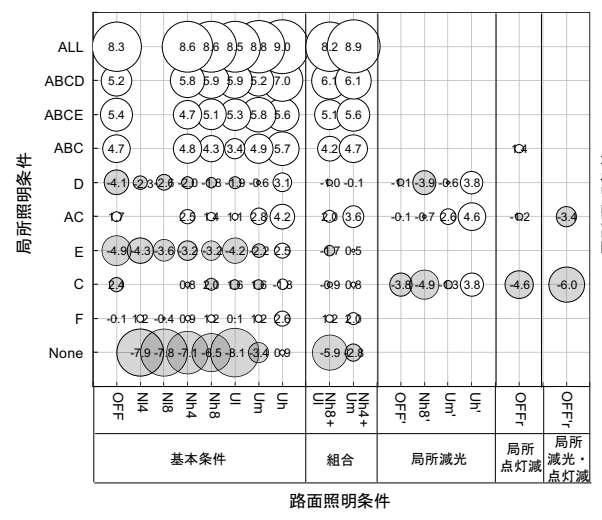

図 8 明るさ感評価結果

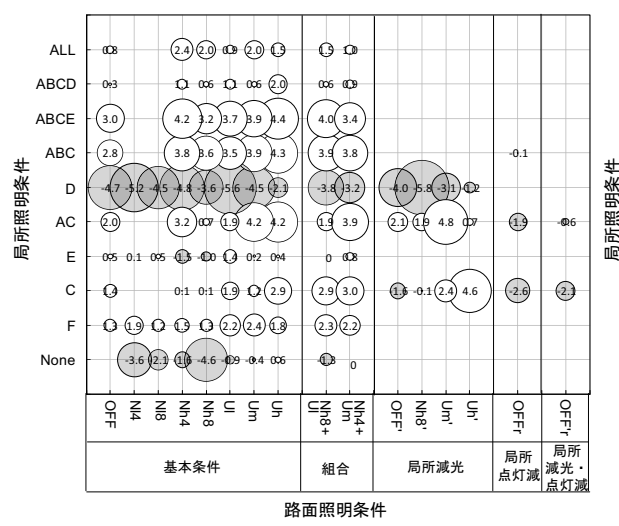

図 11 調和感評価結果

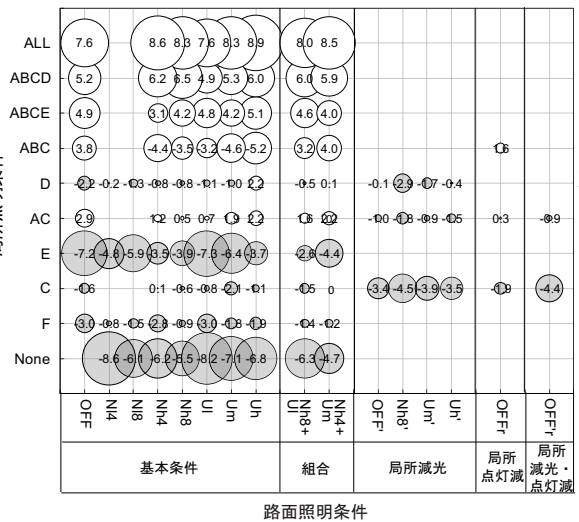

図 9 活動性評価結果

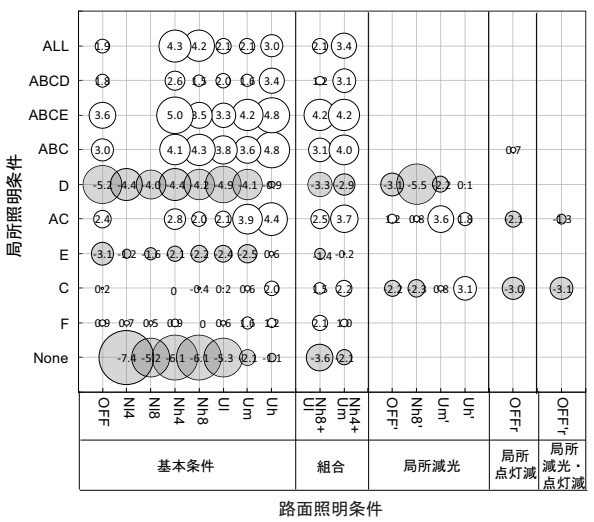

図 12 快適性評価結果

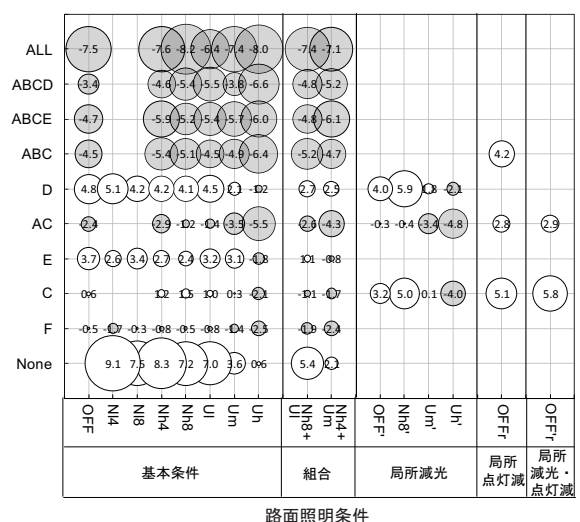

図 10 不安感評価結果

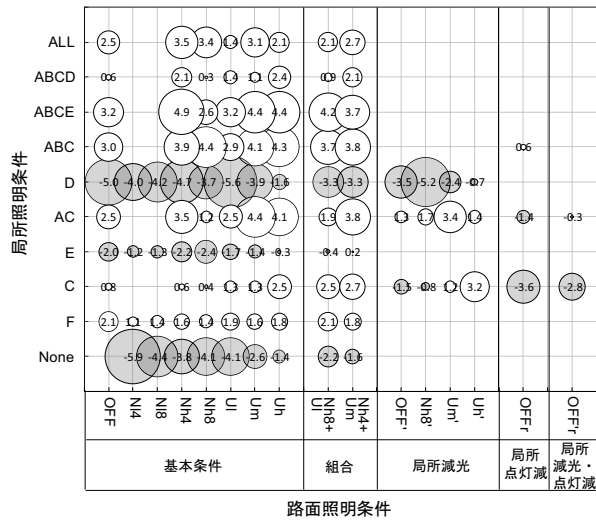

図 13 嗜好性評価結果 
方、路面輝度の中央值と明るさ感評価は高い相関を示している。路 面輝度の中央值は本実験においても夜間街路の明るさ感の評価指標 として有効であることが示された。路面輝度の平均值よりも中央值 の方が明るさ感との相関が高い理由、および建物の鉛直面の輝度の 効果については 4. 考察で検討する。

\section{3. 2 活動性評価}

先行研究 ${ }^{20)}$ では、活動性評価の評価指標の検討を行った。そこで 著者らは、街路空間の活動性の印象が、空間の明るさ感と高い相関 を示すことを見出し、さらに局所的に明るいと感じられる領域の数 が活動性印象に関係することを示した。そこで、明るさ感の評価指 標である路面輝度の中央值と局所的に明るいと感じられる領域（局 所的明所領域) 数を説明変数とした活動性評価指標を提案した。本 報においても、活動性評価指標の結果と上記の 2 変数との関係を検 討した。

図 16 に路面輝度の中央值と活動性評価との関係を示す。シンボル の違いは局所照明条件に対応する。活動性評価が低い範囲において ややばらつきがあるが、路面輝度の中央值と正の相関関係であるこ とがわかる。また、局所照明条件ごとにみると、局所照明の点灯数 が多いほど、活動性印象が高くなることがわかる。このことは、活 動性印象に局所照明の点灯数が影響していることを示唆している。 この点を確かめるためには、局所的明所領域数と活動性評価との関 係を見てみるとよい。

ここで、先行研究 ${ }^{20)}$ で試行した局所的明所領域の選定方法につい てまとめる。局所的に明るい領域の選定を下記のような基準を定め て行った。選択は先述の $25 \times 15$ に分割したグリッド単位で行う。局 所的に明るい領域の選定にあたっては、

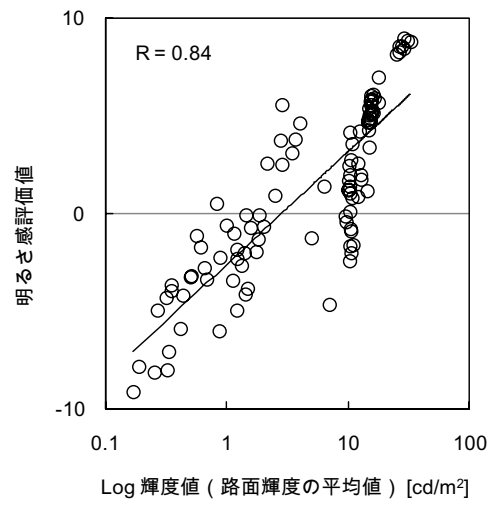

図 14 路面輝度の平均値と

図 17 局所的明所領域数と 活動性評価 明るさ感評価

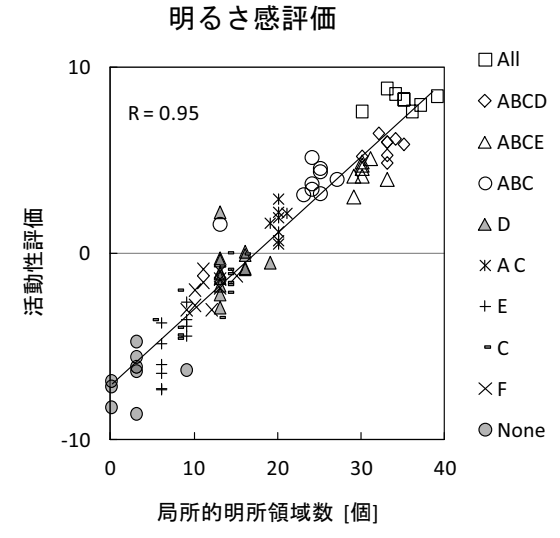

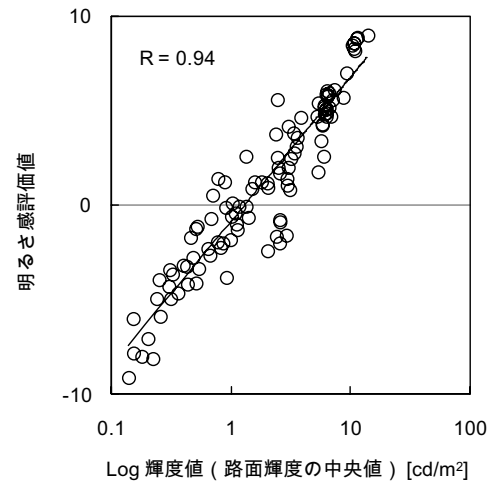

図 15 路面輝度の中央值と 明るさ感評価

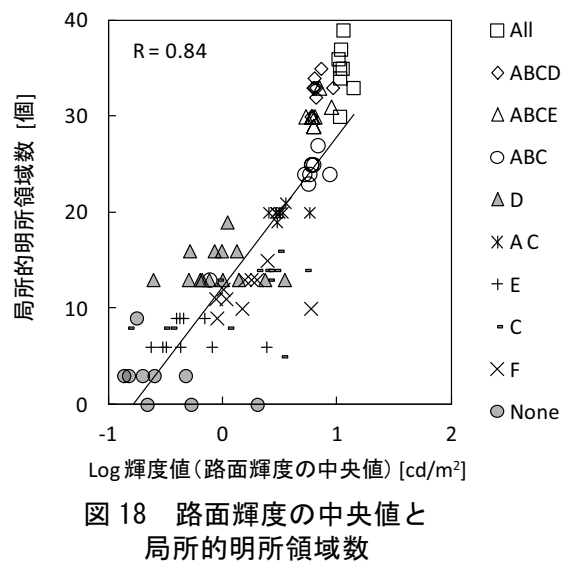

（1）光源自体、または光源によって照明されて周辺に比べて明る いと感じる領域を選択する。

（2）光源とそれによって照射されて明るくなっている領域が連 続している場合は、光源と照射面を個別に選択する。

（3） 1 グリッドの中に光源が複数含まれている場合は、 1 つの明 所領域とする。

（4）広範囲に渡って明るい領域ではなく、周辺に比べて局所的に 明るくなっていると感じる領域を選択する。

グリッド分割の方法を用いることで、1 つのグリッド内に小さい 光源が多く存在する場合でも、それらは 1 つの明所としてカウント されることとなり、実際の照明要素を個別に数え上げる方法とは異 なる。明所領域の算定は照明条件毎の画像を観察して、視感評価に より数え上げた。上記のような判定基準を定めることにより、視感 評価であっても安定した判定が可能であった。

図 17 に、上述の方法により求めた局所的明所領域数と活動性評価 との関係を示す。相関係数 $\mathrm{R}=0.95$ であり、非常に強い正の相関関係 であることがわかる。先行研究 $\left.{ }^{192} 20\right)$ では、局所的明所領域数と活動 性評価との間に正の相関が見られたが、ばらつきも大きかった。本 実験では、観察する街路に含まれる自動車や人、街路の用途などに よる影響を排除した街路模型となっており、このような場合、夜間 街路空間の光環境に対する活動性印象は、空間の光の分布の特徴そ のものによって強く影響されると考えられる。

ここで、路面輝度の中央值と局所的明所領域数の物理量どうしの 関係を確認しておく。局所的明所領域数が増えると、一般に路面輝 度の值も高くなるので、2 変数は正の相関を示すはずである。図 18 に路面輝度の中央值と局所的明所領域数との関係を示寸。予想通り、

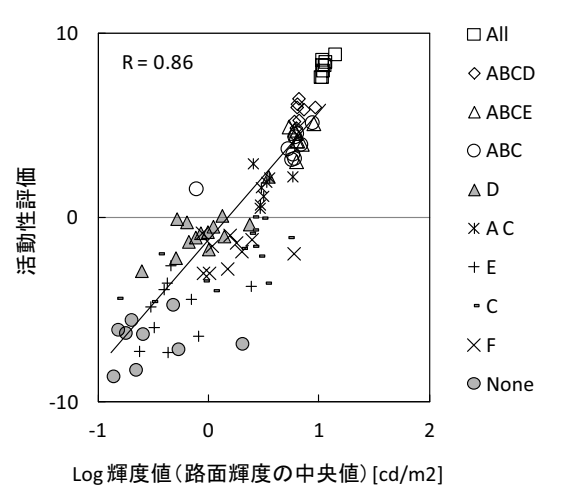

$\log$ 輝度値 (路面輝度の中央値) $[\mathrm{cd} / \mathrm{m} 2]$

図 16 路面輝度の中央值と 活動性評価

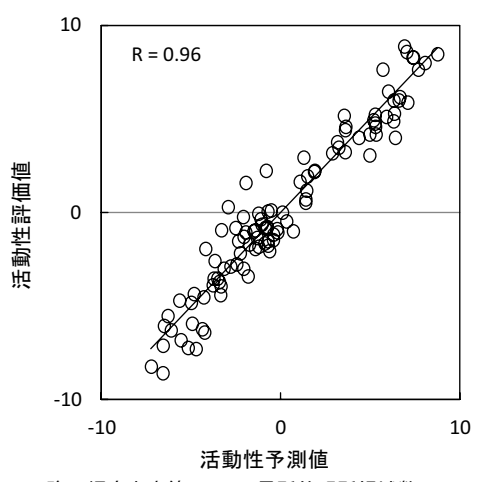

$1.72 x$ 路面輝度中央值 $+0.33 x$ 局所的明所領域数 -6.12

図 19 活動性予測値と 活動性評価値 
局所的明所領域数が上がるほど、路面輝度の中央值が上がる傾向で あった。しかし、局所照明が少ない条件では、2 変数の増減が乘離 することがわかる。これは局所照明による路面輝度への影響が小さ く、主として路面照明が路面輝度に寄与している範囲であろう。局 所的明所領域数と路面輝度の中央值は関係寸るものの、完全に一致 する量ではなく、光の分布の異なった特徴を捉えていると考えるこ とができる。

さて、活動性評価值に対して路面輝度の中央值と局所的明所領域 数を説明変数として重回帰分析を試みた。それによって算出した活 動性評価の予測值と、活動性評価との関係を図 19 に示す。ここでの 相関係数 $\mathrm{R}=0.96$ であり、路面輝度の中央值あるいは局所的明所領域 数との単独の相関に比心゙、相関関係は高くなった。一般の夜間街路 を考慮するならば、これら 2 変数を用いた活動性評価指標が有効と なるだろう。

\section{3.3 不安感および評価性印象}

本研究で行った不安感、調和感、快適性、および嗜好性の評価值 を、照明環境の主要な心理量である明るさ感および活動性を 2 軸と する座標上に布置して、これらの心理量の関係性を検討した。

図 20 に、それぞれの照明条件に対する不安感評価を明るさ感およ び活動性を 2 軸とする座標上に位置づけた結果を示す。白いシンボ ルが正の值、灰色のシンボルが負の值を示し、不安感評価の絶対值 とシンボルの大きさが対応している。図より明らかなように、活動 性および明るさ感が高いと不安感が低く、活動性および明るさ感が 低いと不安感が高くなる傾向であることがわかる。また、活動性が 低く明るさ感が高い場合、不安感がやや低くなる領域がある。これ
は、静的な印象による不安な印象が明るさの印象によって軽減され ていることを示唆している。

図 21 に調和感評価結果を示す。活動性および明るさ感が正值とな る中程度の領域に調和感のピークがあることは、図 11 の結果と整合 する。また、活動性と明るさ感が負值の場合も、その中程度の領域 に調和感の低くなる条件が集中していることは興味深い。

図 22 に快適性評価、図 23 に嗜好性評価の結果を示す。これらの 評価は基本的に調和感の評価結果と類似した傾向を示している。た だし、快適性と嗜好性の評価は活動性、明るさ感が最小となる領域 で最低の評価となっている。

\section{4. 考察}

\section{1 夜間街路の明るさ感指標の統計量}

著者らの先行研究 ${ }^{19)}{ }^{20}$ おおよび本研究の結果は、夜間街路空間の明 るさ感が路面領域の輝度分布の中央值と高い相関を示すことを明ら かにした。その理由として、夜間街路空間の明るさ感がその空間に 拡がる光の量によって強く影響されると考えた。これは室内空間に おける明るさ感の研究 ${ }^{14)}$ からも示唆される。そうだとすれば、街路 空間の明るさ感を評価するためには、その空間に拡がる光の量をう まく記述する物理量を指標とすればよい。さて、空間に拡がってい る光は路面のベースとなる明るさ（局所的な明るさではなく、全体 的な明るさ）を構成するはずである。この路面のベースの明るさに 対応寸る物理量、その一つが路面輝度の中央值である。ただし、路 面のベースの明るさを良好に表現する物理量であれば、別の物理量 も指標になり得るだろう。それは将来的な検討課題である。

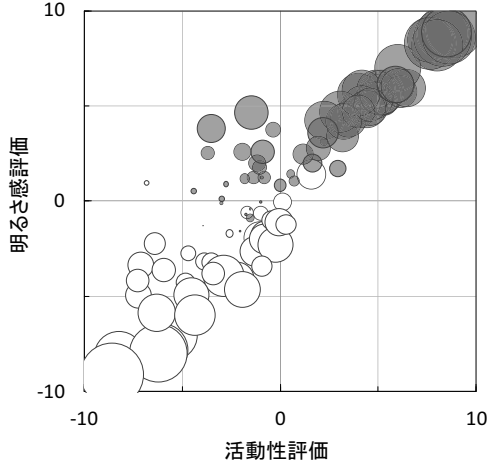

図 20 不安感評価結果

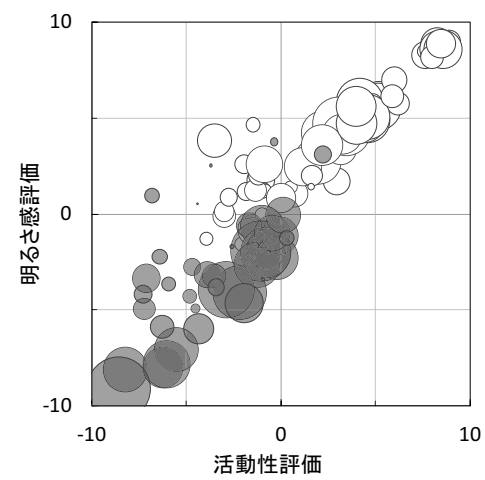

図 23 嗜好性評価結果

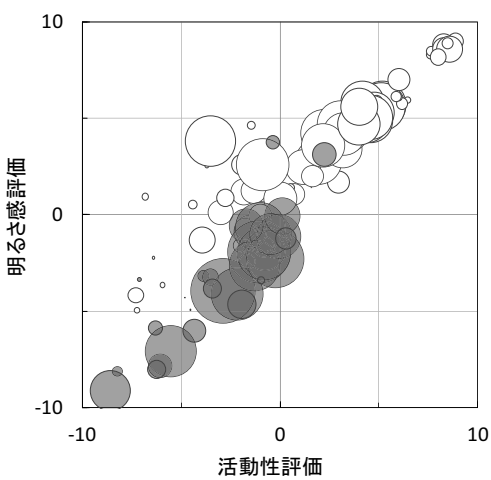

図 21 調和感評価結果

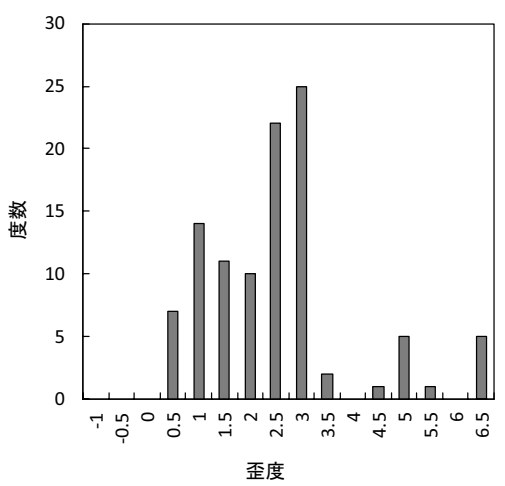

図 24 路面輝度値の歪度頻度分布

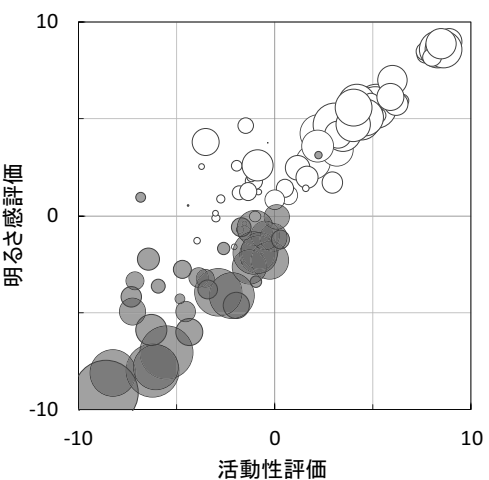

図 22 快適性評価結果

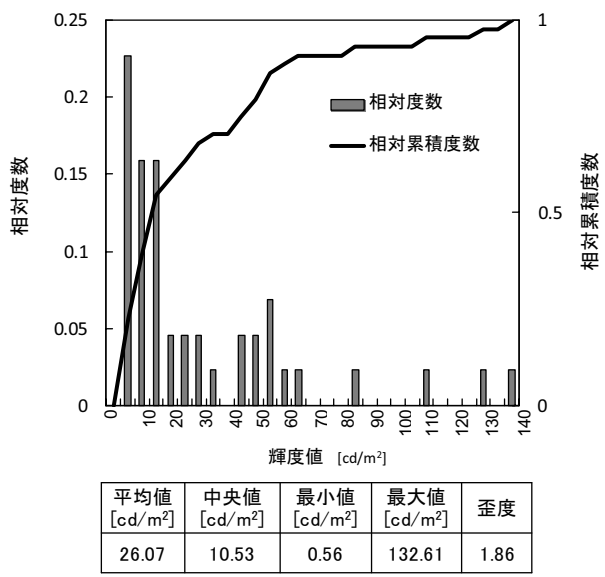

図 25 路面輝度值の頻度分布 (歪度 1.86) 
では、路面輝度の平均值よりも中央值の方が街路空間の明るさ感 と良い相関を示すのは何故か。これには、夜間街路の路面領域の輝 度の度数分布の形状が関係していると考えられる。すなわち、一般 に夜間街路の輝度の度数分布は正規分布ではなく、高輝度の方向に 延びた歪度が大きい分布を形成しているものが多い。街路の明るさ に強く影響する要素が局所的な高輝度領域ではなく、路面のベース となる明るさであるとすれば、歪度が大きい度数分布においては中 央值の方が輝度度数分布の山を捉えた統計量となる。平均值は高輝 度領域の影響を受けや寸く、全体の分布よりも高い值に偏りがちで ある。

図 24 に本実験で設定した照明条件における路面領域の輝度度数 分布より得られた歪度の分布を示す。歪度の值が 0 に等しいとき、 路面輝度の度数分布の形状が正規分布の形となり、0 より大きいほ ど右裾広がりの分布となり、0 より小さいほど左裾広がりの分布と なる。図 24 に示されているように本実験の全照明条件において路面 輝度の度数分布の歪度が 0 以上であることがわかる。また、一例と して、図 25 に歪度 1.86 となった照明条件の路面領域の輝度度数分 布を示す。中央值の方が平均值よりも輝度度数分布のピーク、すな わち路面に広く拡がっている明るさの特徴を反映していることが示 されている。

\section{2 鉛直面方向の輝度が夜間街路空間の明るさ感評価に与える影響}

夜間街路の明るさ感に影響する要素がその空間に拡がる光の量で あるとすれば、その指標としては路面の輝度情報だけではなく、建 物等の鉛直面の輝度情報も有力な手掛かりになり得るだろう。実際、 本実験の結果では鋁直面（壁面）の輝度の中央值も明るさ感評価と

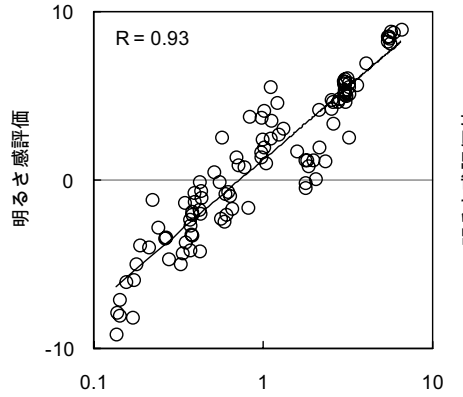

$\log$ 輝度 (鉛直面輝度の中央値) $\left[\mathrm{cd} / \mathrm{m}^{2}\right]$

図 26 鉛直面輝度の中央值と 明るさ感評価

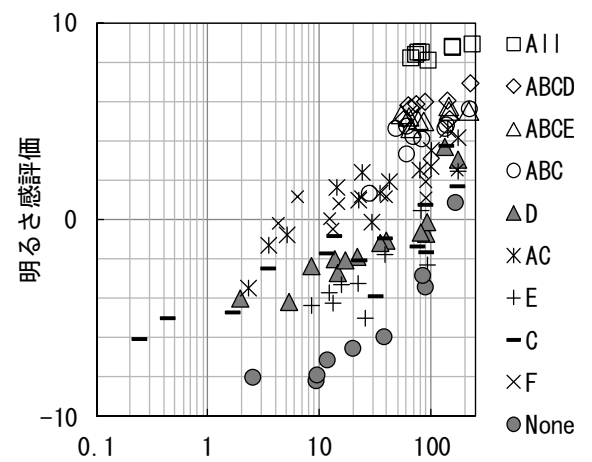

$\log$ 路面照度 平均値 $[\mathrm{Ix}]$

図 28 路面平均照度と 明るさ感評価

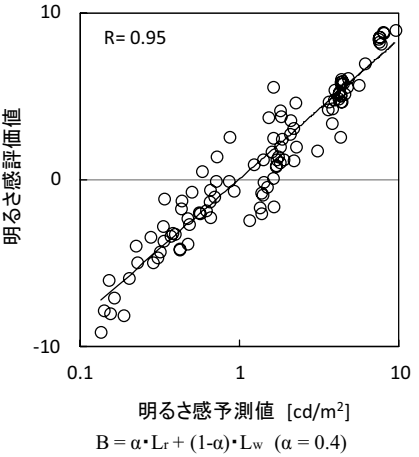

図 27 明るさ感予測值と 明るさ感評価値
高い相関関係が得られた（図 26）。路面あるいは地面は屋外空間に 必ず存在する面であることを考えると、その輝度情報を評価の基準 とする妥当性は高いが、鉛直面も含めて全体的な輝度情報を有効に 活用することができれば、より汎用性が高い評価モデルが構築でき るだろう。

本論文では、試みとして、路面輝度の中央値と鉛直面輝度の中央 值を変数として、それらの重み付けの線形式と明るさ感評価との相 関を検討した。

このモデルでは、夜間街路空間の明るさ感は式 (1)で示される。

$$
\begin{aligned}
& \mathrm{B}=\alpha \cdot \mathrm{L}_{\mathrm{r}}+(1-\alpha) \cdot \mathrm{L}_{\mathrm{w}}- \\
& \mathrm{B}: \text { 夜間街路空間の明るさ感 } \\
& \mathrm{L}_{\mathrm{r}}: \text { 路面輝度の中央值 } \\
& \mathrm{L}_{\mathrm{w}}: \text { 鉛直面輝度の中央值 } \\
& \alpha: \text { 係数 } \\
& \text { ただし、 } 0 \leqq \alpha \leqq 1
\end{aligned}
$$

$\alpha$ を 0.1 間隔で動かし、明るさ感評価值と式(1)で表された明るさ 感予測值が、最も高い相関を示す $\alpha$ を求めたところ、 $\alpha=0.4$ となっ た。この明るさ感予測值と明るさ感評価值との関係を図 27 に示す。 明るさ感予測值との相関係数が 0.95 であり、路面輝度のみおよび鉛 直面輝度のみの結果に比べて、やや高い相関結果が得られたが、今 回は顕著な改善は見られなかった。路面以外の面の輝度情報も考慮 した総合的な評価モデルは将来的な検討課題である。

\section{3 路面照度の平均値および均斉度と明るさ感評価との関係}

これまでに歩行者のための屋外照明基準として街路の路面照度の 平均值および均斉度が定められている ${ }^{2)}$ 。そこで、本実験で街路模 型に対して設定した各照明条件の路面照度の平均值および均斉度と 明るさ感評価との関係について検討する。模型内の路面照度值の測 定 (KONICA MINOLTA 色彩照度計 CL-200A, T\&D Corp. 照度ロガ一 TR-74Ui) では、路面の中心線上で各建物の正面および建物間を測定 地点とし、計 23 か所を測定した值を用いて平均值および均斉度（照 度の最小值/平均值) を求めた。

図 28 に路面照度の平均值と明るさ感評価との関係を示す。これよ り、平均照度が上がるほど明るさ感が上がる傾向であるが、ばらつ きも大きく、同じ程度の路面平均照度值でも明るさ感に差があるこ とがわかる。模型の路面はつや消し表面の素材を使用したことを考 えると、路面の照度と輝度はおおよそ一定の関係を有しているはず

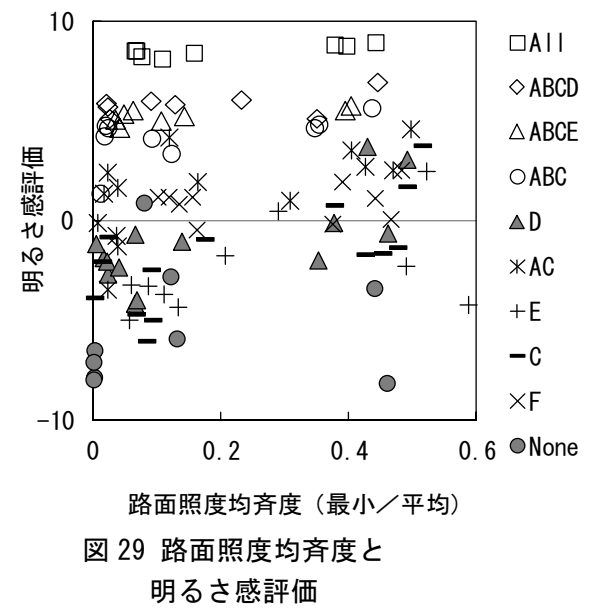

明るさ感評価

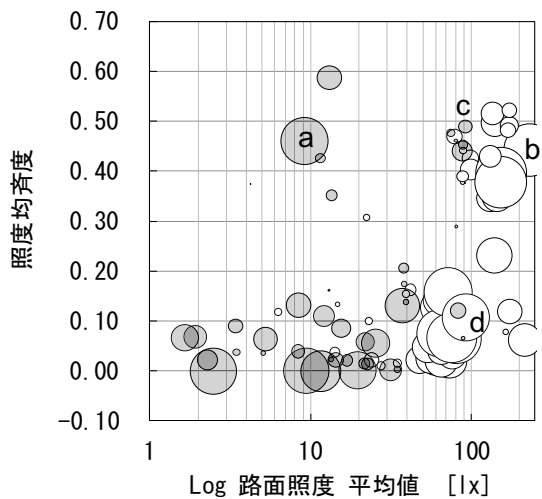

図 30 路面照度と均斉度を考慮 した明るさ感評価 
である。実際、図 28 に示した路面平均照度と明るさ感評価の関係と、 図 14 に示した路面の平均輝度と明るさ感評価の関係には類似した 傾向が見られる。しかし、やはり明るさ感との相関は路面照度值よ りも路面輝度值の方が良いようである。視覚的な印象は目で見る街 路空間によって決まることを考えると、眼に入る光の情報を表寸輝 度が空間の視覚印象の評価に有効な変数となると考えられ、路面に 対する光の分布を工夫した照明計画を行うような場合には、路面輝 度の分布情報が有益な情報となることが考えられる。あるいは、今 回の実験には路面に対する照明に局所的分布がある条件も含まれて おり、照度測定点の取り方が路面平均照度と明るさ感評価のばらつ きの一因になった可能性も考慮しておく必要がある。

次に、光のばらつきを示す照度の均斉度と明るさ感評価との関係 を図 29 に示寸。均斉度と明るさ感とには明確な関係性が見られない ことがわかる。さらに、路面平均照度を横軸、照度均斉度を縦軸と した時のそれぞれの明るさ感評価を図 30 に示す。図中のプロットの 大きさは被験者平均値の正の值および負の值が大きくなるほど大き くなり、白プロットは被験者平均值が正の值、灰プロットは負の值 である。例えば、図 30 に示すa（照明条件 U1-OFF）とb（照明条件 Uh-ABCD） はほぼ同じ均斉度の約 0.45 で比較的均一な光環境である といえるが、明るさ感は大きく異なる。これは $\mathrm{a}$ と $\mathrm{b}$ で平均照度が 異なることが影響していると考えられる。また図中に示す c (照明 条件 Um-E）とd（照明条件 U1+Nh8-A11）では、ほぼ同じ平均照度約 901x であるが、明るさ感評価は大きく異なる。これは均斉度が大き く異なることが影響すると考えられる。以上のように、平均照度や 均斉度は明るさ感評価の指標として単独で説明力がある指標になり づらいと考えられる。本論文で示した路面輝度の中央值は明るさ感 評価との相関係数が 0.94 と非常に高く、精度良く明るさ感を予測で きる指標であると言える。

\section{5. まとめ}

本研究では、街路模型を用いて夜間街路の印象評価実験を実施し、 著者らがこれまでに提案した明るさ感および活動性印象の評価指標 の検討を行った。さらに、不安感、調和感、快適性、嗜好性の印象 評価を明るさ感と活動性を 2 軸とする座標上に布置し、これらの心 理量の関係性を検討した。その結果、明るさ感においては、実際の 街路画像を用いた画像評実験 $\left.{ }^{19}\right)$ と同様に、路面輝度の度数分布の中 央值と高い相関関係が得られ、路面輝度の中央值が夜間街路の明る さ感評価の良好な指標となることが示された。また、活動性におい ては、明るさ感指標と局所的照明領域数によって子測可能であるこ とが示された。ただし、街路画像の評価とは異なる傾向も見られ、 活動性評価は局所的明所領域数との相関関係がより高くなった。本 実験で用いた模型は抽象化された街路であり、街路の立地、人物や 自動車など光環境要素以外の影響が抑えられている。その場合、夜 間街路空間に対する活動性印象は、空間内における光の分布そのも のの影響が優位となった可能性がある。不安感については、明るさ 感評価と高い相関関係が得られ、空間の明るさレベルによる影響が 大きいことが示唆された。

本研究では光の特徴量と印象評価との関係を明らかにしたが、実 際の街路空間における照明設計では、人物の存在、隣接する建物や 路地など建物、街路の形状など様々な要素が加わる。今後は、本報
で示した評価指標の実空間における有効性の検証が必要であると考 える。これらの評価指標に基づいて、住宅地や商業地など場所別に 光環境を検討する場合、それぞれの空間構成に求められる明るさや 活動的、安心な印象などを設定し、適切な指標值の設定を行う照明 設計の方法についても検討を進めたい。

\section{謝辞}

本研究の一部は日本学術振興会特別研究員奨励費 $(25 \cdot 2164)$ の助成 を受けた成果の一部である。

\section{$* 1$ デジタルカメラを用いた輝度分布算出の性能}

本実験で用いた模型内および実空間の輝度を比較するためにデジ タルカメラ（Canon PowerShot G11）から得た撮影画像のデータを用 いて輝度值の算出を行った。方法は、まずデジタルカメラを用いて 実際の夜間街路 25 か所において写真撮影を行った。撮影では、デジ タルカメラのダイナミックレンジをカバーするために、シャッター スピードを $1 / 2 、 1 / 60 、 1 / 2000$ の 3 段階設定した。なお絞りはF 2.8 、 感度はIS0400、ホワイトバランスは量天で固定した。また、撮影と 同時に、各街路において街路内で高輝度に相当する光源部分、路面 中央、街路内で低輝度に相当する路面などの影の 3 か所の輝度值を、 色彩輝度計（KONICA MINOLTA CS-200）を用いて測定した。実測輝度 值と色彩輝度計を用いて測定した箇所のデジタルカメラの画像デー タより算出した輝度とを比較した結果を補図 1 に示す。決定係数 0.969 と非常に高い相関関係が見られた。このことから、本実験に おいて、デジタルカメラを用いて模型内の輝度の測定を行った。

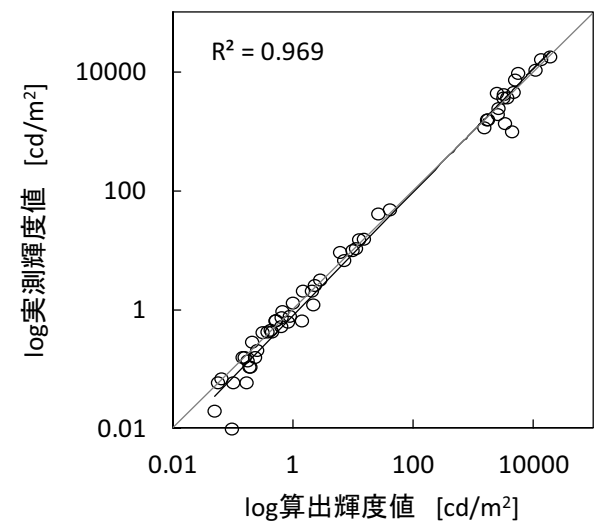

補図 1 実測輝度値と算出輝度値

\section{参考文献}

1）歩行者に対する道路照明基準：JIS Z 9111-1988.

2）照明学会技術指針，歩行者のための屋外公共照明基準 : JCIE-006-1994

3）小林茂雄、角舘政英、名取大輔 : 街路の隣接する空地の見通しを高めた 屋外照明の提案一岐阜県白川村の平瀬地区を対象として一、日本建築学 会環境系論文集、No.621,pp.1-7, 2007, 11

4) Fotios S. A., Cheal C. : Lighting for subsidiary streets: Investigation of lamps of different SPD. Part 2 - Brightness, Lighting Research and Technology, Vol. 39, pp.233-252, 2007

5) Rea M.S., Bullough J.D., Akashi Y. : Several views of metal halide and high pressure sodium lighting for outdoor applications, Lighting Research and Technology, Vol. 41, pp.297-320, 2009

6) Fotios S. A. and Cheal C. : Predicting lamp spectrum effects at mesopic levels. Part 1: Spatial brightness, Lighting Research and Technology, Vol.43, pp.143-157, 2011 
7）白倉公隆、明石行生、斎藤孝: 街路照明の分光特性が空間の明るさに及 ぼす影響、照明学会誌, Vol.96, pp.259-271, 2012

8) Flynn, J.E.: A study of subjective responses to low energy and nonuniform lighting systems, the Illuminating Engineering Society, pp.167-179, 1977

9）田淵義彦、中村肇, 長谷川吾郎：雾囲気分析に基づくリビング空間の照 明技法の開発、照明学会誌、Vol.69, No.10, pp.563-569, 1985

10）明石行生、向健二、明石泉 : 住宅リビングルームにおける行為に対応し た照明条件、照明学会誌、Vol.78, No.11, pp.599-603, 1993

11) Shepherd A.J., and Julian W.G.: Gloom as a psychophysical phenomenon, Lighting Research and Technology, Vol.21, pp.89-97, 1989

12) Loe, D. L, Mansfield, K. P. and Rowlands E.: Appearance of lit environment and its relevance in lighting design: Experimental study, Light Research and Technology, Vol.26, No.3, pp.119-133, 1994

13) Iwai W., Saito Y., Sumi S. and Sakaguchi T.: Sensation of Brightness for a Living Room with Downlights, Journal of Light and Visual Environment, Vol.25, No.1, pp.1-6, 2001
14）荻内康雄、石田泰一郎：仮想輝度分布法による実大空間の明るさ感推 定に関する検討、日本建築学会環境系論文集、No.583, pp.7-14, 2004, 9

15）山口秀樹、篠田博之：色モード境界輝度による空間の明るさ感評価、照 明学会誌、Vol.91, No.5, pp.266-271, 2007

16）山路英洋、石田泰一郎 : 光環境の活動性印象と光の空間的分布特性との 関係、日本建築学会環境系論文集, No. 609, pp.1-6, 2006, 11

17）山下葉:夜間の公共空間の快適性評価実験について, 日本都市計画学会 学術研究論文集 (23), pp. 445-450, 1988

18）大井尚行, 平手小太郎, 安岡正人 : 時刻変化に伴う心理量の変化: 都市 景観評価における変動要素の影響に関する研究 その 1 , 日本建築学会計 画系論文集, No. 453, pp. 45-51，1993，11

19) MOCHINAGA Aimi, ISHIDA Taiichiro: How does street light affect our psychological impression?, Proceedings of AIC 2012 Interim Meeting, Taipei, pp.466-469, 2012

20）持永愛美、石田泰一郎 : 街路模型を用いた夜間街路の光環境が心理的印 象評価に与える影響、日本色彩学会誌、Vol.37, pp.574-575, 2013 


\title{
EVALUATION OF BRIGHTNESS AND ACTIVITY IMPRESSIONS OF OUTDOOR SPACE BY A SCALE MODEL EXPERIMENT
}

\author{
Aimi MOCHINAGA* and Taiichiro ISHIDA** \\ * Graduate Student, Graduate School of Engineering, Kyoto University, M. Life Des. \\ Research Fellow, Japan Society for the Promotion of Science \\ ** Assoc. Prof., Graduate School of Engineering, Kyoto University, Dr. Eng.
}

Outdoor lighting environment in the night-time has been attracting academic interest from the viewpoint of safety precaution and improvement of visibility, expecting prevention of crime or traffic accident. In addition to such functional aspects, psychological impressions are also important in planning outdoor lighting environment, e.g, atmosphere of the street. Therefore, it is believed that a comprehensive design method of the outdoor lighting environment considering both functional and psychological aspects is required.

The authors has conducted an experiment of psychological evaluation using night-time street images, and proposed two indexes that indicate brightness and activity impressions of the street respectively. As for the brightness index, we postulated that human impression be affected by the dominant luminance level over the road surface, which can be given based on median value. It is shown that the activity impression can also be affected by luminance level. In addition, activity impression is also varied by the distribution of luminance, i.e., activity index could be given as a function of both luminance level and distribution.

This paper aims to validate these two indexes, and presents psychological experiment for night time impressions using a scaled street model. The human impression factors associated with lighting environment, i.e., anxiety, harmony, comfort, and preference, are evaluated by subjects, and the effect of above-shown indexes on each human impression is to be shown.

A scaled street model of 1/50 was used, where two building rows were set on both sides. The test model was assumed to have the street of $7.5 \mathrm{~m}$ width and two-story building rows of $8.0 \mathrm{~m}$ width, $6.0 \mathrm{~m}$ height. The road surface was made of the paper whose lightness N2, and as for the building walls, the paper of N9 or N5 was used. In order to make it possible to vary the condition of luminance and its distribution over the road surface, fluorescent lamps and LEDs were provided above the street, on building wall, and on the road surface. The luminous flux of these lamps could be controlled, and lighting pattern in the model could also be varied. Combining conditions of output and lighting pattern, 104 cases were studied in total. Seventeen subjects (9 males, and 8 females) whose average age was 25 participated in the experiment. After 1 minutes observation, subjects evaluated impressions once for each of 104 cases. Here, evaluated factors were "brightness", "activity", "anxiety", "harmony", "comfort", and "preference".

The experimental results shows that proposed brightness index had a strong correlation with brightness impression. This indicates that the median value of the road surface luminance can be a good index to predict brightness impression for the nigh-time outdoor spaces. It is also shown that the activity impression could be predicted based on brightness index and the number of locally bright area. As for anxiety impression, it is highly correlated with brightness impression. This paper showed the effectiveness of proposed indexes based on the scaled-model experiment. As future prospect, these indexes are to be verified and validated in actual outdoor environments. 